5. Dvoretskaya G.V. Sociology: Textbook / G. V. Dvoretskaya K.: KNEU, 2009. 472 c.

6. Sublubna N. Social disadaptation of schoolchildren: prevention and correction. Psychologist. School world 2017. No. 18/19. Pp. 21-32.

7. Lukashevich M.P., Semigina T.V. Social work (theory and practice): a textbook. Kyiv: Karavela, $2011.368 \mathrm{p}$.

8. Maksimova N. Y. Psychological aspects of the problem of training specialists for working with deviant adolescents. Problems of Deviant Behavior: History, Theory, Practice / N. Yu. Maximov // Materials of Allukr. sciences practice Conf., November 25-27, 2002 / Institute of Psychology. GS Kostiuk of the Academy of Pedagogical Sciences of Ukraine; edit S. D. Maksimenko. K., 2002. pp. 57-61

9. Korotkov P.V. Prophylaxis and Correction of Deviant Behavior of Youth in the Activities of Social Services / P.V. Korotkov Visnyk of Chernihiv National Pedagogical University. Sir : Psychological Sciences. 2013. Issue 114. P. 98-102.

10. Martyniuk I. A. Pathopsychology. Tutorial / IA Martyniuk. K.: Center for Educational Literature, $2008.208 \mathrm{p}$.

Одержано статтю: 15.08 .2019

Прийнято до друку: 29.08.2019

УДК 37.013 .42

DOI: $10.15330 /$ esu. 16.166-174

\section{Галина Лемко,}

кандидат педагогічних наук, доцент,

ДВНЗ “"Прикарпатський національний університет ім.В.Стефаника" (м. Івано-Франківськ, Україна)

Galyna Lemko,

Candidate of pedagogical scienses $(\mathrm{PhD})$,

Assosiate Proffesor, Vasyl Stefanyc Precarpathian

National University (Ivano-Frankivsk, Ukraine)

halyna.lemko@pu.if.ua

\section{Наталія Карпович,}

студент, ДВНЗ “Прикарпатський національний

університет ім.В.Стефаника"

(м. Івано-Франківськ, Україна)

Nataliia Karpovych,

student, Vasyl Stefanyc Precarpathian National

University (Ivano-Frankivsk, Ukraine)

lnatalka63@gmail.com

\title{
ОСОБЛИВОСТІ РОЗВИТКУ І ПОВЕДІНКИ ДІТЕЙ 3 РІЗНИХ ТИПІВ НЕПОВНИХ СІМЕЙ
}

\section{FEATURES OF DEVELOPMENT AND BEHAVIOR OF CHILDREN OF VARIOUS TYPES OF INCOMPLETE FAMILIES}

Стаття присвячена одній з актуальних проблем сочіальной педагогіки - проблема різноманітних особливостей розвитку і поведінки дітей з різних типів неповних сімей. На основі теоретичних та сочіально-психологічних досліджень розкриваються ті важливі значення, які характеризують особливості розвитку $i$ поведінки у дітей відповідно до певного типу неповної сім'ї. В роботі досліджено та проаналізовано особливості взаємовідносин дітей з батьками в різних типах неповних сімей.

Дослідження показало, що у всіх типах неповних сімей переважає мени високий рівень сімейних взасмовідносин. У всіх типах неповних сімей, окрім позашлюбної сім'ї, переважса суворість виховних установок батьків. Діти з розлучених та дистантних сімей більи самостійні, ніж діти з осиротілих та позаилюбни сімей. У дітей з усіх типів 
неповних сімей, окрім осиротілої сім'ї, позитивне ставлення до иколи та вчителів. У всіх типах неповних сімей наявні спільні інтереси між батьками та дітьми.

У результатах дослідження можна побачити, що у всіх типах неповних сімей, окрім позашлюбної сім'ї, на формування позитивних рис у дітей впливали обоє батьків. $У$ неповній сім'ї найчастіие проявлясться високий рівень турботи до матері. Турботу до батька проявляють у всіх типах неповних сімей, окрім позаилюбної сім'ї. $У$ всіх типах неповних сімей, окрім дистантної сім'ї, діти завжди самі розповідають батькам про важливі події у свосму житті, а також, вони вважають, ио саме їхні ліноці викликають найбільиу стурбованість з боку батьків. Всі діти думають, що поява у них негативних рис пов 'язана з трудночами вікового періоду.

Результати дослідження будуть иінними у роботі сочіального педагога. Це дає можливість сочіальному педагогу підібрати адекватні засоби впливу для налагодження взаємовідносин між дітьми і батьками з неповних сімей, що мають підвищену тривожність або виявляють відкриту агресію і схильність до девіантної поведінки.

Ключові слова: сім'я, неповна сім'я, розлучена сім'я, осиротіла сім'я, позамлюбна сім'я, дистантна сім'я.

The article is devoted to one of the urgent problems of social pedagogy - the problem of various features of the development and behavior of children from different types of incomplete families. On the basis of theoretical and socio-psychological research reveal the important values that characterize the peculiarities of development and behavior in children in accordance with a certain type of incomplete family. In this work the peculiarities of relations between children and parents in different types of incomplete families are investigated and analyzed.

The research has shown that in all types of incomplete families, the lower level of family relationships prevails. In all types of incomplete families, apart from the extra-marital family, the severity of parenting educational institutions prevails. Children from separated and distant families are more independent than children from orphaned and extra-marital families. In children of all types of incomplete families, in addition to the orphan family, a positive attitude towards the school and teachers. All types of incomplete families have common interests between parents and children.

In the results of the study it can be seen that in all types of incomplete families, apart from the extra-marital family, both parents were affected by the formation of positive features in children. In an incomplete family, a high level of care for the mother is most often seen. Care for the father is shown in all types of incomplete families, except for an extra-marital family. In all types of incomplete families, apart from a distant family, children always tell their parents about important events in their lives, and they also feel that their laziness is the most worrying parent. All children think that the appearance of their negative features associated with the difficulties of the age.

The results of the study will be valuable in the work of a social educator. This enables social educators to find adequate means of influencing the relationship between children and parents from incomplete families who have increased anxiety or reveal open aggression and a tendency to deviant behavior.

Key words: family, incomplete family, divorced family, orphaned family, extra-marital family, distant family.

Постановка проблеми. У XXI столітті в Україні досить поширеною є криза побудових сімейних взаємовідносин. Сім'я $\epsilon$ головним фактором впливу на становлення особистості майбутнього покоління. Саме сім'я визначає те, хто ми $€, 3$ ким ми спілкуємося і як ставимося до людей навколо нас, наше майбутнє.

Iз соціально-психологічного погляду сім'я розглядається як “...динамічна мала соціальна група людей, поєднана спільністю проживання й родинними 
стосунками, спільністю формування та задоволення соціально-економічних та біологічних потреб, любов'ю, взаємною моральною відповідальністю" [5, с. 12].

Загалом виділяють такі типи сім'ї - повні та неповні. Повні сім’ї характеризуються наявністю у сім'ї обох батьків, які беруть активну і пряму участь у вихованні дітей та постійно проживають разом 3 ними. Неповні сім'ї характеризуються систематичною відсутністю одного з батьків у житті дитини.

Важливу роль у формуванні і розвитку відносин у неповній сім’ї займає залежність співвідносних об'єктів - відносини кровної спорідненості. Саме тому, основою неповної сім'ї $\epsilon$ визначення таких відносин родинного кровного взаємозв'язку. Неповну сім'ю можна визначити як “...динамічну малу соціальну групу спільно проживаючих людей, поєднаних родинними відносинами кровної спорідненості, спільності формування й задоволення соціально-економічних i біологічних потреб, взаємною моральною відповідальністю, що складається з одного з батьків $з$ однією чи декількома неповнолітніми дітьми" [8, с. 6].

Розрізняють чотири основні типи неповної сім'ї - розлучена сім'я, осиротіла сім'я, позашлюбна сім'я та дистантна сім'я. Кожна 3 цих сімей характеризується постійною відсутністю у житті дитини одного з батьків. Але в кожному типі неповної сім'ї причина відсутності одного з батьків різна. Саме тому й поведінка дитини у кожному типі неповної сім'ї зовсім інша.

Аналіз досліджень і публікацій. Проблеми неповних сімей та негативний вплив неповних сімей на розвиток особистості дитини висвітлено в роботах А.Макаренка, В.Сухомлинського, М.Стельмаховича. Різні типи неповних сімей та розвиток дитини під впливом кожного типу неповної сім’ї досліджували М.Докторович, В.Костів, Л.Шпільчак.

Мета статті - обгрунтувати особливості поведінки дітей у різних типах неповних сімей.

Виклад основного матеріалу. Всім добре відомо, що основним фактором, який впливає на розвиток і поведінку дитини $є$ сім'я. Саме сім'я $є$ тим чинником, який допомагає дитині формувати свою особистіть та створювати своє місце в цьому світі. Загалом, вплив сім'ї на розвиток дитини характеризується такими чинниками:

1. Сім'я як основа почуття безпеки. Відносини прихильності важливі не тільки для майбутнього розвитку взаємин - їх безпосередній вплив сприяє зниженню почуття тривоги, що виникає у дитини в нових або в стресогенних ситуаціях.

2. Моделі батьківської поведінки. Діти зазвичай прагнуть копіювати поведінку інших людей і найбільш часто тих, з ким вони знаходяться в самому близькому контакті.

3. Сім'я і придбання життєвого досвіду. Вплив батьків особливо велике тому, що $\epsilon$ для дитини джерелом необхідного життєвого досвіду. Запас дитячих знань багато в чому залежить від того, наскільки батьки забезпечують дитині можливість займатися в бібліотеках, відвідувати музеї, відпочивати на природі.

4. Дисципліна і формування поведінки. Батьки впливають на поведінку дитини, заохочуючи або засуджуючи певні типи поведінки, а також застосовуючи покарання або допускаючи прийнятну для себе ступінь свободи в поведінці дитини.

5. Спілкування в сім'ї. Спілкування в сім’ї дозволяє дитині виробити власні погляди, норми, установки, і ідеї [4].

Залежно від того 3 ким проживає дитина розрізняють материнську i батьківську неповні сім'ї. За кількістю поколінь розрізняють неповну просту - мама 
(тато) 3 дитиною чи кількома дітьми та неповну розширену сім'ю - мама (тато) 3 дітьми та іншими родичами. За способом утворення є такі типи неповної сім'ї: осиротіла, позашлюбна, розлучена та дистантна сім'я.

Тобто, неповна сім'я може утворитися внаслідок смерті одного 3 батьків, народження дитини поза шлюбом, розлучення батьків, розпаду сім'ї при юридичному збереженні сім'ї [6].

Одним із типів неповної сім'ї є розлучена сім'я. Розлучена сім'я - це сім'я, яка утворюється після офіційного розірвання подружнього зв'зку між чоловіком i жінкою за певних обставин. При розлученні дитини залишаться з одним з батьків, що вирішують вони самі шляхом мирної угоди або суд під час процесу розлучення.

Розлучена сім'я $є$ сильним фактором невротизації, характеризується напруженими відносинами між батьками і дитиною, збільшує ймовірність появи девіантної поведінки у дитини.

Деякі зарубіжні дослідники (Д.Макдермот, Д.Валлерштейн) вважають, що найгірше розлучення проживають діти дошкільного віку (2,5-3,5 роки). У них виникають лякливість, проблеми зі сном, зниження пізнавальних інтересів; у дітей старшого дошкільного віку можуть реагувати на розлучення таким чином тривожність, біль втрати, депресія, агресія, знижена самооцінка [1, с. 10].

Дуже негативно на дитину впливає стан матері після розлучення. Зазвичай, мати у всіх проблемах звинувачує батька. Вона виховує в дітей почуття ненависті до батька, що починає шкодити і дітям, і їй, і батькові.

В процесі розлучення в дитини починає змінюватися ставлення до матері. Вона або починає жаліти маму або починає іiі ненавидіти, тому що звинувачує у відході батька, особливо якщо батька любила більше за матір. Відстань між матір'ю і дитиною виникає в тому випадку, якщо після розлучення мати зосереджується на власних проблемах i не має часу на дитину. Тобто, будь-яка 3 цих умов може створити для дитини нездорове середовище.

3 часом дитина починає звикати до свого становища у сім'ї і в неї починають 3'являтися певні комплекси. Дуже важливо для батьків зберегти справедливе відношення до дитини після розлучення. Несправедливість може викликати у дитини образливість, озлобленість, страх, жорстокість. Дитина стає грубою у ставленні до інших людей [7, с. 96-105].

У процесі розлучення у більшості дітей знижується успішність у навчанні. Тоді діти вибирають антиправову поведінку. Дитина починає шукати таке коло спілкування, яке задовольнятиме іiі потреби. Вона починає порушувати дисципліну і шукає визнання серед однолітків. Так вона задовольняє свою потребу в успіху, визнанні та самоствердженні [6, с. 54-60].

Отже, процес розлучення може викликати у дитини такі зміни: відставання у навчанні, невпевненість у позитивній оцінці дорослих, агресивність, цинізм, грубість, використання батьків у власних цілях, ненависть, підвищена потреба у любові, відсутність емоційного контакту з тим з батьків, який проживає окремо та ін. Дитина неадекватно усвідомлює навколишню соціальну дійсність, що може призвести до зміни ціннісних орієнтацій, знищення моральності, появи комплексів. Це все може спровокувати появу антиправової поведінки i негативно впливає на побудову педагогічно доцільних відносин у сім'ї.

До типів неповних сімей належить і осиротіла сім'я. Осиротіла сім'я - це сім'я, яка утворюється в результаті смерті одного з батьків. Смерть одного 3 батьків завжди негативно впливає на нервовий стан членів сім'ї та стабільність батьківських 
почуттів. Дитина з осиротілої сім’ї проживає всі стадії горя, які є визначеними у психології. I саме цей перехід дуже негативно відбивається на психологічному та фізичному розвитку дитини.

В даний період дуже важливо правильно допомогти дитині пережити цю подію. Навіть варто звернутися до психолога, щоб допомогти дитині розібратися зі своїми почуттями. У цей перід існує ризик психічного порушення. М.Раттер говорив, що такий ризик $є$ максимальним, якщо один з батьків помирає, коли дитині 3-4 роки, а також, якщо померлий батько чи мати є однієї статі з дитиною. Це може бути по'язане з статевою ідентифікацією дитини. Значна частина порушень виникає через тривалий час після смерті одного з батьків [9, с. 199].

Дуже важливим фактором, який впливає на стосунки дитини 3 тим 3 батьків, який живий, є зміна ставлення до дитини. У цей період може виникнути збільшення відстані між ними, якщо один з батьків занурений у власне горе i виникненням нових проблем, тому що не мають часу на дитину. Або дитина може розглядатися як тягар, що ускладнює життя одного з батьків. В такому випадку може виникнути грубе, несправедливе ставлення до дитини, що повністю руйнує іiі моральність, так само, як і "сліпа любов", яка немає меж.

Отже, при смерті одного з батьків у дитини зберігається певний ідеал померлого батька чи матері. Дуже важко замінити цей ідеал або поставити когось поруч 3 ним. Дитина втрачає частину своєї особистості, що може повністю змінити іiі поведінку.

Позашлюбна сім'я є одним із типів неповних сімей. Позашлюбна сім'я - це народження жінкою дитини без оформлення офіційних відносин 3 чоловіком. Найчастіше діти з позашлюбних сімей навіть не знають свого батька.

Ставлення до позашлюбних сімей почало змінюватися лише $3 \mathrm{XX}$ ст. До XX ст. позашлюбні сім'ї дуже гостро засуджувались, адже основою суспільної думки була моральність. Дітей мати могли лише заміжні жінки. За українськими звичаями така жінка повинна була покинути сім'ю i місце проживання. За А.Демідовим, позашлюбна сім'я - це такий вид сім'ї, який виник поруч 3 моногамним шлюбом [2]. Тобто, позашлюбні сім'ї фіксувалися ще до XX ст.

Коли з'явився Радянський Союз, кількість позашлюбних народжень зросла. Також, збільшилася кількість позашлюбних народжень після закінчення Другої світової війни, що можна було пов'язати з різким зменшенням кількості чоловіків у країні. Сучасні жінки народжують позашлюбних дітей здебільшого через те, що:

1) це більше не є соціально неприйнятним явищем;

2) сім'я більше не цінується так, як раніше;

3) чоловіки здебільшого бояться відповідальності та утворювати сім'ю;

4) сучасні жінки тепер самі є собі опорою і потреба в чоловіках не така велика;

5) матеріальна незалежність жінок.

Найчастіше поза шлюбом народжують або дуже юні дівчата (15-19 років), або досить старші жінки (40-49 років). Перші - стають матерями несвідомо, а другі свідомо обирають такий шлях, тому що це останній шанс мати сім'ю [3, с. 107].

Жінки з розлученої або осиротілої сім'ї мають можливість розраховувати на якусь аліменти чи пенсію, а от жінки з позашлюбних сімей в матеріальному плані можуть розраховувати лише на себе. $С$ виплати на дітей для матерів-одиначок, але цього не досить, щоб самій виховувати дитину. Саме тому вони повинні працювати. Перша проблема позашлюбних сімей - постійна зайнятість матері. Друга проблема не бажання розповідати про народження дитини. У розлученій сім’ї $є$ уявлення про 
батька (хороше чи погане), у осиротілій сім'ї - батько ідеалізується, а у позашлюбній сім'ї образ батька повністю відсутній або створюється брехлива історія про батька. Третя проблема - стать дитини. У таких сім'ях менше проблем 3 дівчатками, ніж 3 хлопцями. Вчені (М.Буянов, В.Целуйко, В.Васютинський, Л.Івлєва) вважають, що хлопці з позашлюбних сімей більш вразливі, ніж дівчата, тому що їм властиві неадеватна самооцінка, труднощі у спілкуванні, відчуття непотрібності. Вони говорять про відсутність об'єкту ідентифікації, що впливає на статеву ідентичність. Хлопці з позашлюбних сімей або стають безвольними, особливо якщо виховуються в авторитарному стилі виховання, або вульгаризованими, відкидають жіночі стереотипи, тому що орієнтуються на псевдочоловічі якості. Також, відсутність процесу правильної статевої ідентифікації може призвести до розвитку гомосексуальних нахилів.

Отже, діти 3 позашлюбних сімей є дуже чутливими, нервовими, закомплексованими. Також, багато дітей не можуть змиритися з історією свого народження. Їм важко пробачити матерям легковажну поведінку, можуть почати шукати батька, який може навіть не знати про дитину.

Але не завжди стосунки між матір'ю та дитиною в позашлюбній сім’ї не завжди $€$ проблемними або напруженими, при хорошому вихованні матері, сприятливому психологічному клімату в сім’і всі негативні фактор просто стираються [3, с. 106-108].

До типології неповних сімей належить і дистантна сім'я. За визначенням Ф.Мустаєва, дистантна сім'я - це така сім'я, у якій життя для кожного з подружжя проходить більшою мірою окремо, через специфіку професії одного чи обох партнерів [10, с. 152]. Дуже важко визначити кількість дистантних сімей в Україні, оскільки дуже багато людей виїжджають на заробітки закордон нелегально. Особливістю такої сім'ї $є$ їі, нібито, юридична цілісність. Дітям 3 дистантних сімей властиві такі ж якості, як і дітям 3 неповних сімей, так і дітям, які виховуються поза сім'єю. Такі діти дуже сильно сумують за батьками. Коли на заробітках мати, це набагато гірше переживається дитиною, ніж коли на заробітках батько. Відсутність матері діти переживають набагато важче, особливо чим менший вік дитини.

Для даного виду неповної сім'ї $є$ менш характерними матеріальні проблеми, але $\epsilon$ загроза заміни батьківської любові грошима. Батьки намагаються компенсувати батьківську увагу матеріальними речами, що скоріш за все, просто зіпсує дитину. Вони перестають цінувати працю, звикають до матеріального добробуту і починають вимаги більше. Вони не вміють спиратися на власні сили і досить довго потребують допомоги батьків.

Отже, діти 3 дистантних сімей тривалий час знаходяться без батьків, ставлення до батьків часто таке саме, як і в інших неповних сім'ях. Особливості даних сімей в тому, що тут батьки намагаються замінити брак уваги матеріальним становищем. Також, розрив матері між намаганням зберегти шлюб та залишитися 3 дітьми. Дуже важливо в таких сім'ях правильно побудувати відносини так, щоб більше часу приділяти сім'ї [3, с. 108-109].

Відсутність у сім'ї одного 3 батьків може викликати проблеми у статевій ідентифікації дитини, оскільки вона не має змоги спостерігати за правильною побудовою подружніх відносин. Це негативно впливає на майбутню побудову людиною своєї сім'ї. У дитини формуються неправильні уявлення про шлюб і сім'ю. Тобто, сім'ї у яких хоча б один з батьків був з неповної сім'ї розпадаються частіше, ніж де батьки з повних сімей [6, с. 23-24]. 
Загалом, всім типам неповних сімей властиві зміни певних функцій: загалом починає знижуватися реалізація репродуктивної функції, зниження рівня матеріального забезпечення, змінюється дозвілля і ускладнюється психосоціальний розвиток (змінюється емоціний зв'язок між батьками та дітьми, знижується рівень почуття безпеки у дітей, змінюеться сімейна позиція, шкільна позиція, зміни у психічній нестабільності у членів сім'ї, вдновлення психологічної рівноваги).

3 метою практичного вивчення взаємостосунків батьків 3 дітьми-підлітками та їх батьками у неповних сім'ях було проведено дослідження на базі Королівської ЗОШ I-III ступенів №1 Закарпатської області. Проаналізувавши результати дослідження слід зазначити, що у різних типах неповних сімей батьки намагаються приймати своїх дітей такими, як вони є. Вони щиро цікавляться справами своїх дітей та хочуть бути частиною їхнього життя. Батьки прагнуть бути ближчими до своїх дітей, але водночас, вони прагнуть контролювати їхнє життя, тому що хочуть їх захистити від негативного впливу цього світу. Вони вірять у своїх дітей та люблять їх не дивлячись на їхні невдачі.

Для підлітків найважливішими цінностями у житті є здоров'я, вихованість та терпимість. Це показує, що вони цінують своє життя, цінують хороше ставлення та повагу один до одного. Неважливими для підлітків є цінності творчості, ефективності у навчанні, матеріальне забезпечення та непримиренність до недоліків у собі та інших. Це показує, що вони не розуміють цінності творчості та іiі важливості для їхнього життя і майбутнього. У даний віковий період навчання відходить на другий план. Адже важливішою стає дружба та визнання серед однолітків. За матеріальне забезпечення відповідають батьки, які прагнуть максимально задовільнити всіх їхні потреби, тому й важливості грошей вони не знають. Ставлення до недоліків у цей віковий період найбільш толерантне. Адже чим більше у мені недоліків, тим більш гарно я виглядаю у очах однолітків. Вони саме зараз дуже люблять випробовувати стійкість характеру дорослих та один одного. Для дітей у підлітковому віці важливе переважання цінностей особистості, спілкування та конформізму. Вони прагнуть зрозуміти самих себе, бути прийняті іншими і тому дуже легко підпадають під вплив більшості або авторитету (зазвичай, негативному).

У більшості підлітків хороші взаємовідносини з батьками. Вони намагаються підтримувати теплоту в стосунках та формувати довіру. Більшість батьків використовують гнучкість виховних установок для підтримання педагогічно доцільних відносин 3 підлітками. Вони допомагають дітям формувати самостійність та позитивне ставлення до школи. Батьки використовують гнучкі методи виховання та мають багато спільних інтересів 3 своїми дітьми. Вони завжди допомагають дітям і підтримують їх, намагаючись зберегти хороші відносини. Підлітки більше довіряють матері і тому вона є більшим авторитетом для них. Вони швидше до мами підуть просити про допомогу та діляться своїми проблемами і враженнями. Це можна пояснити тим, що саме у неповних сім'ях діти майже завжди залишаються з матір'ю.

На формування позитивних рис підлітки вважають, що найбільше впливають обоє батьків, навіть якщо один з них постійно відсутній у їхньому житті саме зараз. Підлітки завжди ставляться до обох батьків з чуйністю, дбайливістю та турботою. Вони завжди самі розповідають батькам про свої переживання, враження та таємниці. Найбільш негативними рисами, які вони мають підлітки називають лінощі та небажання вчитися. Саме ці негативні риси викликають занепокоєння у їхніх батьків. Причиною появи негативних рис у своїй особистості підлітки називають труднощі вікового періоду. Вони пояснюють це зміною своєї особистості та зміною 
власних цінностей. Відсутність обох батьків у житті дитини не дає змогу оцінити вплив сімейних сварок на їхню успішність у школі.

Висновки. Проблема розвитку і поведінки дітей у різних типах неповних сімей $\epsilon$ дуже широкою для дослідження. Адже неповні сім'ї не охоплюють лише чотири основні типи. Їх є набагато більше (наприклад, батьки юридично одружені, але проживають окремо; батьки проживають у громадянському шлюбі та ін.). Приблизно половина неповнолітніх в Україні певний період життя проживають в умовах неповної сім'ї. Цьому дуже сприяє ситуація виїзду багатьох громадян на заробітки за кордон, а також, участь чоловіків у військових подіях за останні 5 років.

Ставлення людей до неповних сімей за останні століття дуже змінилися. Розлучення, позашлюбна сім'я більше не осуджуються так активно, як колись. Тепер це звичайна норма, яка нікого не дивує. Це може бути пов'язано зі зміною моральних цінностей, які пропагуються суспільством.

Отже, неповна сім'я може негативно впливати на успішність та творчість дитини, iї моральний розвиток, ціннісні орієнтації, життєву позицію та готовність до сімейного життя, але найчастіше це відбувається лише при поєднанні комплексу несприятливих обставин, які негативно діють на психіку людини.

Що стосується взаємостосунків у дітей-підлітків 3 неповних сімей, то можна сказати таке: діти 3 неповних сімей дуже самостійні і витривалі. Вони більше схильні до різних видів девіацій, але більше прив'язані до одного з батьків. Тут є дві крайності - дитина 3 неповної сім'ї або повністю віддана одному з батьків, або відірвана від обох батьків. Тобто, або слухається, або робить лише по своєму. Тут батькам дуже важко встановити контакт 3 підлітком, оскільки він вважає себе зрадженим і кинутим. До того ж дуже сильно в цей період на характер і поведінку підлітка впливає фізичний розвиток. Тому взаємостосунки між батьками і дітьмипідлітками в цей віковий період значно ускладнюються.

\section{Література}

1. Гаврилова Т.П. К проблеме влияния распада семьи на детей дошкольного возраста. Семья и формирование личности: НИИ ОП АПН СССР/ Общ. ред. А. А. Бодалёва. Москва, 1981. С. 1015

2. Демидов А.М. Особливості життедіяльності неповних сімей. Сім'я і соціальна структура. Москва, 1987. 234 с.

3. Докторович М.О. Соціально-педагогічна робота 3 дітьми 3 неповних сімей: навч.-метод. посібник для студ. ВНЗ. Київ: Ленвіт, 2010. 152 с.

4. Земска М.В. Семья и личность: пер. с польского Л.В.Васильева / Общ. ред., послесл. М. С. Мацковского. Москва: Прогресс, 1986. 133 с.

5. Ковбас Б.І., Костів В.І. Родинна педагогіка: У 3-х т. Том 1. Основи родинних взаємовідносин / ред. Б.І. Ковбаса, В.І. Костіва. Івано-Франківськ: Плай, 2002. 288 с.

6. Костив В.И. Внебрачная семья. Неполная семья. Осиротевшая семья. Приемные дети. Семейное воспитание: краткий словарь. Москва: Политздат, 1990. 206 с.

7. Костів В.I. Характеристика морального процесу у системі ціннісно-нормативної регуляції поведінки особи: Збірник наукових праць: філософія, соціологія, психологія / За ред. С.Возняк, Л. Орбан. Івано-Франківськ, 1996. Ч.2. С.96-105.

8. Костів В. Консультативна робота з проблем родинного виховання у неповній сім'ї. Серія "Педагогіка, етнопедагогіка". Випуск 24. Івано-Франківськ, 1998. 116 с.

9. Раттер М. Помощь трудным детям: пер. с англ. / Общ. ред. А. С.Спиваковской; предисл. О. В. Баженовой и А. Я. Варга. Москва: Прогресс, 1987. 424 с.

10. Соціальна робота в Україні: теорія та практика. Посібник для підвищення кваліфікації працівників соціальних служб для молоді. / За заг. ред. доц. А. Я. Ходорчук . Київ, 2003. 272 с.

References

1. Havrylova T.P. K probleme vlyianyia raspada semy na detei doshkolnoho vozrasta. Semia y formyrovanye lychnosty: NYY OP APN SSSR/ Obshch. red. A. A. Bodalëva. Moskva, 1981. S. 10-15. 
2. Demydov A.M. Osoblyvosti zhyttiediialnosti nepovnykh simei. Simia i sotsialna struktura. Moskva, 1987. $234 \mathrm{~s}$.

3. Doktorovych M.O. Sotsialno-pedahohichna robota $z$ ditmy $z$ nepovnykh simei: navch.-metod. posibnyk dlia stud. VNZ. Kyiv: Lenvit, 2010. $152 \mathrm{~s}$.

4. Zemska M.V. Semia y lychnost: per. s polskoho L.V.Vasyleva / Obshch. red., poslesl. M. S. Matskovskoho. Moskva: Prohress, 1986. $133 \mathrm{~s}$.

5. Kovbas B.I., Kostiv V.I. Rodynna pedahohika: U 3-kh t. Tom 1. Osnovy rodynnykh vzaiemovidnosyn / red. B.I. Kovbasa, V.I. Kostiva. Ivano-Frankivsk: Plai, 2002. 288 s.

6. Kostyv V.Y. Vnebrachnaia semia. Nepolnaia semia. Osyrotevshaia semia. Pryemnyie dety. Semeinoe vospytanye: kratkyi slovar. Moskva: Polytzdat, 1990. 206 s.

7. Kostiv V.I. Kharakterystyka moralnoho protsesu u systemi tsinnisno-normatyvnoi rehuliatsii povedinky osoby: Zbirnyk naukovykh prats: filosofiia, sotsiolohiia, psykholohiia / Za red. S.Vozniak, L. Orban. Ivano-Frankivsk, 1996. Ch.2. S.96-105.

8. Kostiv V. Konsultatyvna robota $z$ problem rodynnoho vykhovannia u nepovnii simi. Seriia "Pedahohika, etnopedahohika". Vypusk 24. Ivano-Frankivsk, 1998. $116 \mathrm{c}$

9. Ratter M. Pomoshch trudnyim detiam: per. s anhl. / Obshch. red. A. S.Spyvakovskoi; predysl. O. V. Bazhenovoi y A. Ya. Varha. Moskva: Prohress, 1987. $424 \mathrm{~s}$.

10. Sotsialna robota $\mathrm{v}$ Ukraini: teoriia ta praktyka. Posibnyk dlia pidvyshchennia kvalifikatsii pratsivnykiv sotsialnykh sluzhb dlia molodi. / Za zah. red. dots. A. Ya. Khodorchuk . Kyiv, 2003. $272 \mathrm{~s}$.

Одержано статтю: 11.07.2019

Прийнято до друку: 25.07.2019

УДК 159.9.01

DOI: 10.15330/esu. 16.174-181

\section{Світлана Литвиненко,}

доктор педагогічнах наук, професор,

Рівненський державний гуманітарний

Університет (м. Рівне, Україна)

Svitlana Lytvynenko,

Doctor of pedagogical sciences, Professor,

Rivne state humanitarian the university

(Rivne, Ukraine)

sa.litv50@gmail.com

\section{ФЕНОМЕНОЛОГІЯ ГРИ ТА ІГРОВӦ̈ ДІЯЛЬНОСТІ: СУЧАСНІ ПІДХОДИ}

\section{PHENOMENOLOGY OF GAME AND GAME ACTIVITIES: MODERN APPROACHES}

У статті здійснено аналіз досліджень феномену гри в сутнісно-буттєвому вимірі та розкрито провідні підходи щодо визначення сутності, ознак, особливостей та функиій гри. Доведено, ио гра є природним, органічним елементом та витвором людської культури, закономіриим результатом еволючій, ио засвідчус ї̈ приналежність до ефективних засобів особистісного розвитку та сочіалізаџії людини, засвоєння нею смислів, культурних норм $і$ традицій. До провідни характеристик гри належать: свобода, спонтанність $i$ активність, тобто діяльність позбавлена управління й програмування; взаємодія $з$ використанням різних предметів і засобів (матеріальних та не матеріальних), наповненість практичними діями й рухливістю; відсутність прагматичних цілей та результатів; пережсивання приємних емоџій та задоволення, пов 'язаних з самим прочесом грu.

Ключові слова: феномен гри, гра, ознаки і функиії гри.

The article analyzes the research of the phenomenon of the game in the essence-existential dimension. The leading philosophical, culturological and psychological approaches to the definition of the essence of the game are presented. It is proved that the game is a natural, organic 